\title{
Indonesia Human Capital Competitiveness in the ASEAN Economic Community (AEC) Era
}

\author{
Acep Durahman \\ HR. Concentration of Magister Management Program \\ Universitas Pendidikan Indonesia \\ Bandung, Indonesia \\ Email: acepdurahman@gmail.com
}

\begin{abstract}
ASEAN Economic Community (AEC) is the Free Trade Area among ASEAN Members States (AMSs). Goods and services had been freed entrance a country after the establishment of MEA by December 2015 [1]. The implementation of MEA had the negative and positive impact on AMS especially Indonesia [2]. The AEC agreement contain five aspect that its distribution can't be limited are goods distribution, services distribution, capital market, the investment, and skilled and trained workers. The Government of Indonesia has regulate foreign labour in ministry regulation (Permen) Number 162005 to protect local labour. The Province Minimum Wage (UMP) Issue will be correlated to AEC implication on Indonesia industrial climate. The AEC forces the Indonesia human capital to become more skilful and fully trained, otherwise the competition will be dominated by most proper country.
\end{abstract} Labor

Keywords-AEC, ASEAN, Human Capital Competitiveness,

\section{INTRODUCTION}

ASEAN Economy Community (AEC) had been declared for decades. Since its initiate in 1988, its execute for fist implementation by the end of 2015. While the AMSs more integrated, all members prepare for the competition by providing the great physical capital, training the human capital, the comprehension government regulation and increasing the citizen educational level. In contrast, among emerging and developing economies, Malaysia scored the highest at number 18, while Indonesia global competitiveness index dropped tree places to 37 from 34 in 2014-15[3]. The AEC is a part of regional coordination and should enhance nation competitiveness [4].

Pursuing regional economic integration has gained prominence in ASEAN affairs over succeeding decades. From the initial focus on trade liberalization, through the Preferential Trading Arrangement and eventually the ASEAN Free Trade Agreement (AFTA), ASEAN's regional economic integration agenda has broadened to now include services trade, investment, labour migration, and even macroeconomic policy. ASEAN's regional economic integration efforts are meant to culminate in the creation of an ASEAN Economic Community. Although it's there are different definition between integration and cooperation. Integration is a FTA (Free Trade Area) and cooperation is an action [5].
The AEC does not guarantee or seek full labour mobility even among the highly skilled [6]. Its seem to be considered that cooperation among ASEAN members should give the equal benefit each other, otherwise, the unequal partnership will end AEC journey such as Britain Decision to leave EU (Brexit) by June 2016. The Brexit will make the migrant worker future unsure [7]. Although it's dominated by the security issues among EU countries.

The cooperation and integration among ASEAN member states (AMSs) based on four pillars are: (1). Single market and production base, (2). Competitive Economic Region, (3). Equitable Economic Development, (4). Integration into Global Economy [8]. The single market and production will make the distribution of goods, services, investment, and a big number of capital market borderless in South East Asia region. The competitive economic region comprise the political will of competition policy, consumer protection, Intellectual Property Right (IPR/HaKI, Hak atas Kekayaan Intelektual), taxation policy, and e-commerce. Therefore, the fair climate competition will be built, and the consumer to be protected, and avoid the IPR violation, create the efficient transportation network, safety and integrated, reducing double taxation, and to grow the electronic base trade (online). The equitable economic development means the economic development which make the Small and Medium Enterprises (SMEs) as a priority. SMEs competitiveness will be developed and facilitated to the updated information access, access the market condition, developing human resources or human capital. Finally, they could strengthen the capacity, the finance, and increase technology

Through created and integrated economic community, the AEC would encourage high-cost production countries such as Singapore and Malaysia to move its production base to the lower-cost ones such as Laos, Cambodia and Burma. This the only one of the AEC impact. The corporation will consider which country has a lowest minimum wage. The government should choose the best policy between low labour wage and high unemployment caused by the company relocation to the other country. This will affect the number of unemployment. It's to be decreased or increased. 
Where:

EBIT: Operating Profit (Earnings before Interest \& Taxes)

EC : Employment Cost

FTE: Labour to a full-time equivalent (average headcount)

The other way to measure human capital is by balance scorecard approach. The balanced scorecard (BSC) is a strategy performance management tool that gives managers a fast but comprehensive view of business [13]. Organizations can use a system that identifies a number of financial and nonfinancial measures, and attach targets to them, which are reviewed to determine whether current performance 'meets expectations', which is the main characteristic. The BSC method use several key performance indicator are: 1) Human Capital ROI, 2) Employee satisfaction index, 3). Pay for performance, 4). Resource Competency Index/gap, 5). Employee capability score, 6) Employee engagement, and 7). Absenteeism rate [14]

The human capital competitiveness which author discuss comprises 1) The worker key performance indicator 2). The Province minimum wage \& AMSs, 3). The Industrial Climate that's depend on labour stability. 4) The Nation and Industrial Productivity. The human capital indicators which more specific can be observed on the following table:

TABLE I. HUMAN CAPITAL INDICATOR (WEF INDEX)

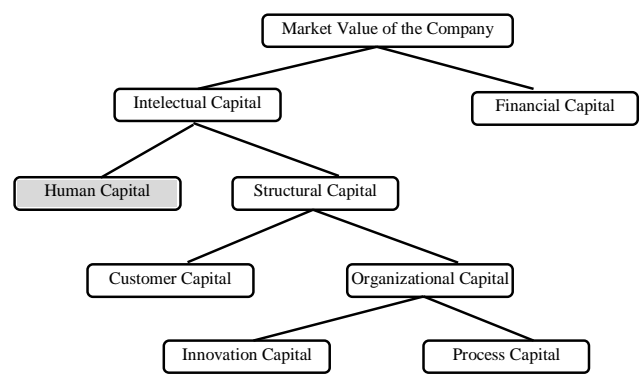

Fig. 1. The Role of Human Capital

From the figure above, we say that the human capital is a part of intellectual capital in a company and it will determine the it's market value [11].

The Human Capital Competitiveness is the power, resources and capabilities of man to do something relative to one or more competitor.

There are several method to get the value of human capital. Fitz define human capital as HVCA (Human Capital Value Added). The formula could be composed below:

Human Capital Value Added [12]:

$$
I C V A=\frac{E B I T+F C}{F T E}
$$

\begin{tabular}{|c|c|}
\hline \multicolumn{2}{|c|}{ WEF Human Capital Indicator } \\
\hline $\begin{array}{l}\text { Indicator Linked with education } \\
\text { and training }\end{array}$ & $\begin{array}{l}\text { Indicator linked with human } \\
\text { capital }\end{array}$ \\
\hline $\begin{array}{l}\text { - Quality of Primary Education } \\
\text { - Primary enrolment } \\
\text { - Education expenditure } \\
\text { - Secondary enrolment } \\
\text { - Tertiary enrolment } \\
\text { - Quality of the educational } \\
\text { system } \\
\text { - Quality of science and } \\
\text { mathematics education } \\
\text { - Quality of management schools } \\
\text { - Internet access in schools } \\
\text { - Local availability of research } \\
\text { and training services } \\
\text { - Extent of staff training }\end{array}$ & $\begin{array}{l}\text { - Brain-drain } \\
\text { - Capacity for innovation } \\
\text { - Quality of research } \\
\text { institutions } \\
\text { - Company spending on } \\
\text { research and development } \\
\text { - University-industry } \\
\text { research collaboration } \\
\text { - Availability of researchers } \\
\text { and engineers } \\
\text { - Utility patents }\end{array}$ \\
\hline
\end{tabular}
Indonesia ranking indexed as number 37.

The human capital needed to be measured because it can use for making the proper management which can create the company value. The measurement could be a Key Performance Indicator (KPI) based, or Productivity based according to the indicator which will be measured by the company.

The figure 2 below described several KPI used to measure the human capital level. This measurement usually use the Balance scorecard approach. Here is the figure:
According to the Human Capital indicator above, 


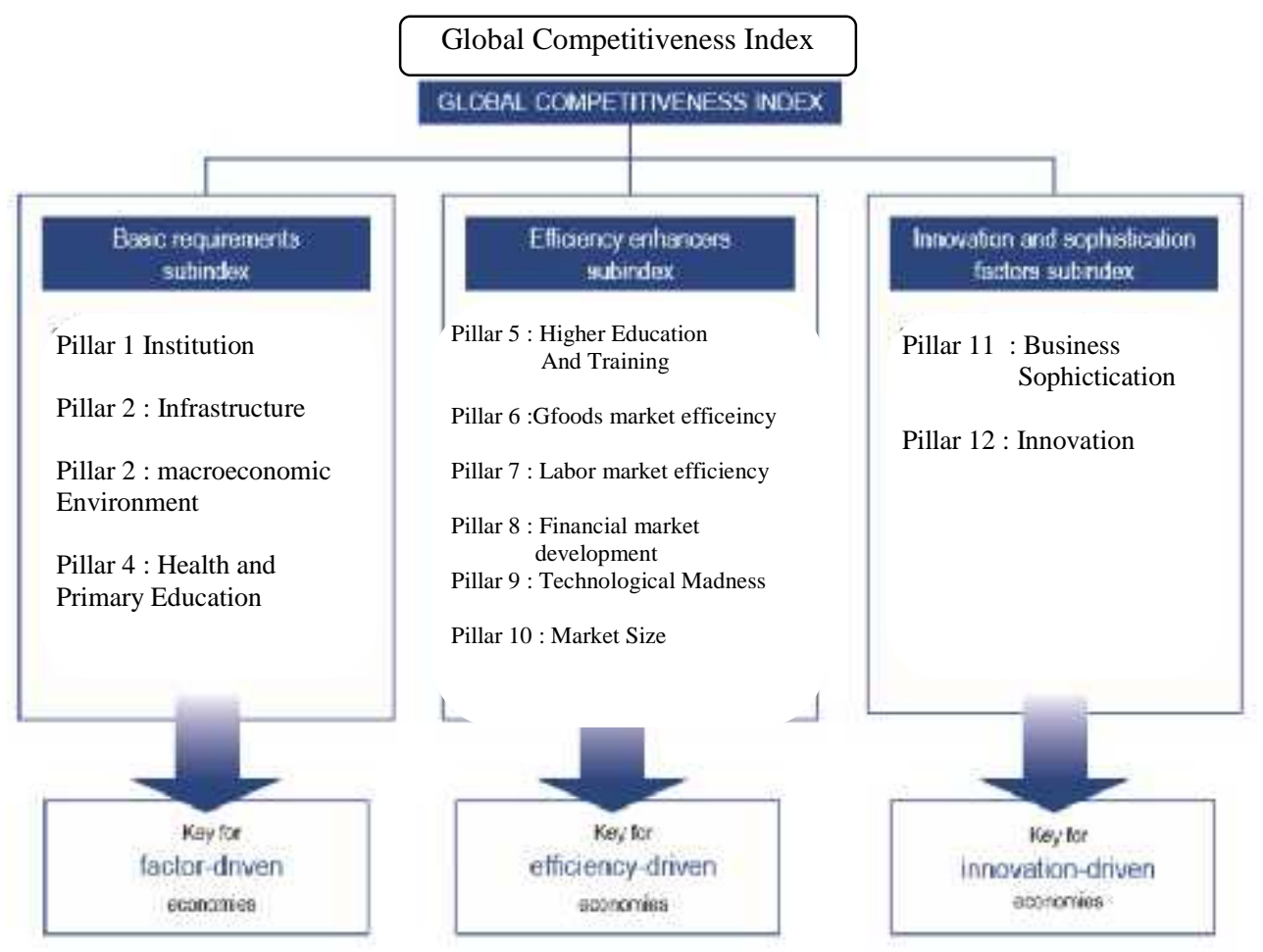

Fig. 2. the KPI used to measred Human Capital

\section{B. The Indonesia Human Capital in number}

The short description of Indonesia Human Capital could be observed through several indicator are: 1) the citizen average educational level (High School /Undergraduate). 2). The Number of employment and unemployment, 3). The Economic growth 4). Industrial climate or labour stability.

Since 2010 until 2015, the Indonesian labour usually make a demonstration to ask to the government and company to increase the minimum wage. So that the manpower ministry make regulation for wage regulation called Province Minimum Wage (UMP). By 2016 the government as part of tripartite (Labour, company and government) decide the minimum wage for Jakarta about 3 million rupiah (231 USD). The decision legitimated by the government regulation (PP No 78 Tahun 2015) about the employee compensation [15].

Indonesian Statistic Agency (BPS) release that the number of people who has a job about 120 million (75\%) by February 2015 [16]. Total Indonesia population about 250 million people, $7 \%$ of them jobless or unemployed [17]. The UN predict the population will be 290 million by 2045

The table below describes job vacancy and the accepted worker by the year 2014 .

TABLE II. THE ACCEPTED WORKER ${ }^{\mathrm{b}}$

\begin{tabular}{|c|c|c|}
\hline Job Applicator & The Job Vacancy & Accepted Applicant \\
\hline $1,295,149$ & 816,505 & $625.187(48 \%)$ \\
\hline \multicolumn{2}{|c}{${ }^{\text {b. }}$ Bada Pusat Statistik }
\end{tabular}

The data shows that just only $48 \%$ of job applicator who seek the work can be accepted by job provider (48\%). Thus we can conclude there are a number of unemployment in 2014 about $52 \%$. This person percentage could be jobless or they role play as an entrepreneur. Need the advanced survey to calculate it.

\section{The Indoneisa minimum wage (UMP)}

There are several decision procedures to get the regional minimum wage (UMR/UMP). The components that play role are: 1). the compensation council, 2). the Government (Governor/regent), 3). KHL (The Basic Life Need). Here are the number of UMP (minimum wage) for each Province in Indonesia (representative by 4 Provinces) that decided on January 2016:

TABLE III. INDONESIA MINIMUM WAGE ${ }^{\mathrm{b}}$

\begin{tabular}{|l|l|l|}
\hline \multicolumn{1}{|c|}{ PROVINCE } & \multicolumn{1}{c|}{\begin{tabular}{c|} 
THE MINIMUM \\
WAGE (IDR)
\end{tabular}} & INTERPRETATION \\
\hline $\begin{array}{l}\text { Jakarta Capital } \\
\text { Region }\end{array}$ & $\begin{array}{l}3.100 .000 \\
(231 \text { USD) }\end{array}$ & The higest \\
\hline North Sulawesi & 2.400 .000 & High \\
\hline West Java & 2.250 .000 & Middle \\
\hline North Maluku & 1.680 .000 & Low \\
\hline Bengkulu & $\begin{array}{l}1.600 .000 \\
(119 \text { USD) }\end{array}$ & The lowest \\
\hline
\end{tabular}

The table above indicate that the maximum wage IDR 3.100.000 (231 USD) and IDR 1.600.000 at the minimum. This price of employee cost considered by the investor who will invest in Indonesia. More infestation comes, the rate of employed people will be increased. The investment indexed by the number called Foreign Direct Investment (FDI) which will affect the nation competitiveness. Thus, the wage average become one of the topic to be discussed this paper.

The other labour issue in Indonesia is the rationalization of civil servant (PNS/Pegawai Negeri Sipil) by 2017[18]. With this program, the government through the ministry of civil servant empowerment (MENPAN) will reduce about 1 million civil servant gradually. The performance appraisal will be applied to measure their productivity. The worker which has the lower productivity will be retired. 


\section{ASEAN Members State Wage Comparison}

The following description will compare the minimum wage and its decision mechanism among several ASEAN Member States (AMSs) [19]:

\section{a) Vietnam}

Recent years in Vietnam have been pivotal in terms of new labour regulations, and 2016 will be no different. On January 1st, 2016 Vietnam's regional minimum wage increased by $12.4 \%$ according to Decree No. 122/2015/ND-CP. The above minimum wages are subject to adjustment every year, and will be in place from January 1 st - December 31st of each year. In July or August, the National Wage Council - part of the Ministry of Labour, Invalid and Social Affairs - will also propose minimum wage schemes. Following this proposal, the prime minister's approval is required but in the event of a confirmed wage increase it will be 3 months before these adjustments will be put in place. This gives companies ample time to adjust their budget and forecast for the next year and makes compliance easier.

\section{2) Singapore}

The topic of minimum wages is hotly debated in Singapore. While many developed economies have long engaged in paying minimum wages, Singapore has no such system in place. Instead, wage rates are determined by the open market - raising concerns over too many low-paying jobs. Since there are no official minimum wages, we can only give some facts. The median gross monthly income from work in 2015 was US\$ 3,949 for full-time employed residents; much higher than the national minimum of SS 1,000 (US706.5) a month proposed by the Singapore Workers Party last year.

The recapitulation of average wage across ASEAN nations can be described as table below [20]:

TABLE IV. AVERAGE AMSS WAGE ${ }^{\mathrm{b}}$

\begin{tabular}{|l|l|l|l|}
\hline No & \multicolumn{1}{|c|}{ Countries } & $\begin{array}{c}\text { Amount of wage } \\
\text { (IDR) }\end{array}$ & \multicolumn{1}{|c|}{ Category } \\
\hline 1 & Singapore & 35.800 .000 & The Higest wage \\
\hline 2 & Brunei & 16.000 .000 & Height wage \\
\hline 3 & Malaysia & 11.600 .000 & Height wage \\
\hline 4 & Thailand & 6.300 .000 & Middle wage \\
\hline 5 & Myanmar & 4.500 .000 & Middle wage \\
\hline 6 & Philipine & 4.300 .000 & Middle wage \\
\hline 7 & Vietnam & 3.700 .000 & Low wage \\
\hline 8 & Indonesia & 3.600 .000 & Low wage \\
\hline 9 & Cambodia & 2.500 .000 & The Lowest wage \\
\hline 10 & Laos & 2.100 .000 & The Lowest wage \\
\hline
\end{tabular}

The table describes that the highest wage among ASEAN Members States is the Singapore wage which pay the labour 35.800.000 IDR (2.753 USD). The lowest wage found in Laos by 2.100 .000 IDR (161 USD) in employee payment each month The Indonesia minimum wage place at low level wage about 3,700.000 (284 USD).

The writer argue that Indonesia wage as a competitive wage enough. Because the wage described on the table is the average wage for daily worker. The high level manager wage and company top executive did not describe yet this paper.

\section{MEA IN PROGRESS}

Since MEA declared on December 2015 and it's begin on January 1, 2016, there are several progress and achievement of this economic integration. Without considering the negative impact here are some progress MEA implementation:

\section{A. MEA IN ACTION}

The next passage below will describe how the AEC implementation impact any sector in several ASEAN Member States. That impact we call it by the MEA Progress.

The MEA Progress demonstrates the potential of the AEC more than evidence of commercial viability. In a region accustomed to corporate realities, ASEAN can already look to home-grown, successful companies that have made business happen in the economic community and beyond.

As seen from the experiences of a highly diverse range of firms, across different sectors, the AEC provides both multinationals and SMEs with both region-wide and localmarket opportunities for creating prosperous regional and international businesses. Here are some evidence of AEC progress:

\section{1) Brand Reach}

. A Singapore's Super Group reach company's partnership with US firm Proctor and Gamble in 2004, which was at the time the owner of the PRINGLES POTATO chip brand. Super has since become Pringles exclusive manufacturer worldwide outside the US, a huge feat for an Asian, regionally- based firm

\section{2) From Small to Large}

A key player in Viet Nam's economic revival also built its fortunes on coffee: Trung Nguyen Coffee Corporation, or better known internationally for its $\mathrm{G} 7$ brand, is a producer, manufacturer and retailer of coffee products and is based in Ho Chi Minh City. Founded in 1996, the company has been developing its production capacity while creating a number of quality brands by 2013. R\&D and Human Resources units were set up and the company learned about vertical integration. It then created ready-for-sale, premium brands for the domestic and international market.

\section{3) Corporate Transformation}

"Transformation" is a continuing theme for ASEAN companies that have taken advantage of the AEC. Indonesia's company, WIKA (PT. Wijaya Karya) is a case in point. Founded as an electrical supplies and water pipe fitter in 1960, WIKA has been transformed into a holding company in construction, engineering procurement construction (EPC) and investment, with 10 subsidiaries.

WIKA has moved into distinct sectors, among them industry, infrastructure and building, energy and industrial plant construction, realty and property, as well as investment. In addition to its contractor operations, WIKA also produces a variety of quality concrete products through its subsidiary, WIKA Beton, and asphalt through WIKA Bitumen. WIKA has also ventured into oil and gas and the electric generation sectors 
approach, financial approach, human capital approach, and macroeconomic.

A key focus of ASEAN's initiatives has been on improving connectivity through better logistics and transport systems. International Container Terminal Services, Inc., (ICTS) of the Philippines is a port management company that was established in 1987, and has since been cited by the Asian

Development Bank as one of the top five major maritime terminal operators in the world ICTS was established by Enrique Razon, whose family has been managing harbours in the Philippines for three generations.

\section{5) Multinational Investor Confidence}

ASEAN's development has not been lost on international companies keen to take advantage of business opportunities they see emerging with the establishment of the AEC as a single investment destination.

Japan-based, global automotive component manufacturer Denso Corporation has operations in five ASEAN countries, and has benefitted from the trade facilitation provisions of ATIGA and the Self-Certification pilot project. Employing more than 22,000 people and with US\$2.9 billion of investments in ASEAN.

\section{6) Higher Value ASEAN}

For ASEAN-based companies themselves, such regional and global commitments have raised the stakes on the quality and sophistication of their output. Ingress Company is a Malaysian automotive components manufacturers and a recent recipient of "ASEAN Economic Community Priority Integration Sector Award in Automotive" at the 6th ASEAN Business Awards Malaysia in 2015

\section{7) AEC 'Makes Business Happen'}

The AEC has created an environment for ASEAN's home grown businesses, old and new alike, large and small, to thrive, evolve, and expand their market reach. Beyond 2015, as the effects of the AEC are further developed and felt, and as ASEAN implements its vision for the Community for the next 10 years, more businesses and individuals are expected to participate in, and benefit from regional economic integration

\section{DISCUSION}

The opinion which says:"Trying be efficient at producing things more cheaply is important. And to do this well, a country need not only a cheap labour force, a country need an educated labour force also" [21]. According to the writer opinion, the cheap labour force is the indicator should be more considered again today. It's no longer compatible to the recent challenges. The high cost labour now happen in Indonesia.

\section{SUMMARY}

- The ASEAN Economic Community (AEC) has begun by January 1, 2016, and will make the region of South East Asia more integrated area. The AEC is a part of ASEAN Community which consist of ASEAN Political-Security Community (APSC) and ASEAN Sosio-Culture Community

- The AEC is a comprehensive cooperation and integration. It must be analysed by the marketing
- Commonly most of ASEAN Member States (AMSs) are developing or emerging country, below EU or USA. Thus, its need the integration of economy to make the region more competitive.

- Indonesia competitiveness at the "medium level", and will face it with the defensive strategy.

- The human capital is a part of a number capitals, such as financial capital, consumer capital, physical capital these will determine the value of a company or a nation.

- The unpredicted impact of AEC such as economic disintegration or economic crisis need to be watched by the ASEAN secretariat. This aim to anticipate the "Brexit" impact which will make the ASEAN disintegrated.

- Single ASEAN currency to be considered as an instrument of regional financial integration.

- Its need to hold a Memorandum of Understanding (MoU) among The ASEAN about the ASEAN labour minimum wage.

The wage solution is try to be solved by holding the ASEAN manpower (Menteri Tenaga Kerja) meeting. The agreement could contain about AMSs minimum wage. This will make the nation compete fairly, no country decide the minimum wage lower than another. If not, the company will move to the country that have the lowest wage, such as Cambodia and Vietnam.

This paper suggested to the broad public audiences as a pre-reference for the further AEC research. It's possible to make survey among migrant worker in Indonesia about the job application easiness, compensation, organizational culture and other variables that support Indonesia competitiveness locally (ASEAN) and globally (worldwide). The respondent could be a daily worker, middle managers or top managers in an Indonesia multinational company, such as PT. Freeport Indonesia, PT. Chevron Indonesia (Mining Industry), PT. Nissan Motor Indonesia, PT. Astra Honda (Automotive Industry), PT. Kahatex, PT. Buma Apparel (Garment Industry), Citibank, Nobu Bank (Banking Industry) etc.

\section{REFERENCES}

[1] Lee, Casey \& Yoshifumi F., ASEAN Regional Cooperation on Competition Policy, Journal of Asian Economic, Page 3-25

[2] Setiawan, Arman, The Positive and Negative impact of MEA for Indonesia" (Dampak Positif dan Negatif Masyarakat Ekonomi ASEAN -MEA- bagi Indonesia),2016. Online

[3] Global Competitiveness Report 2015-2016

[4] Porter, Michael E, Improving Indonesia's Competitiveness", Presentation to SBY, 2009.

[5] Bela Balasa, The Theory of Ecomomic Integration Greenwood Press.1961 
[6] Sugiyarto, Guntur, Dovelyn Rannveig Agunias, A Freer Flow of Skilled Labor Within ASEAN : Aspirations, Opportunities, And Challenges in 2015 and beyond. Migration Policy Institute. Issue No 14, 2014

[7] Alderman, Liz 'Brexit' Vote Has EuropeanWorkers in Britain Unsure of Future. The New York Times. 2016.

[8] ASEAN. ASEAN Economic Community BLUE PRINT.

[9] Becker, Gary S. Human Capital .The University of Chicago Press. 1993

[10] Goldin, Claudia, Human Capital, Handbook of Cliometric, 2014

[11] Edvinsson, L., Developing Intellectual Capital in Skandia, Long Range Planning, Vol 30, No 3 Page 320-331.1997.

[12] Meszek, Wieslaw, Measurment of Human Capital in the Specificity of a construction enterprise. Procedia Enginering 122 Page 213-219, 2015

[13] Harvard Business Review, The Balanced Scorecard: Measures That Drive Performance, Kaplan, Robert S., and David P. Norton, JanuaryFebruary 1992
[14] Verma, Abhishek, Human Capital, Designing and Measuring Human Capital Key Performance Indicator, 2015

[15] Niam, Farik The Karl Marx Theory analitical on PP No 782015 the wage regulation (Analisis Teori Kar Marx dalam PP No 782015 tentang pengupahan), 2016.

[16] Ministry Secretariat, BPS: The employed citizen increase 6,2 Million, and unemployement decrease 5,81\%”, 2015

[17] Anonym, Unemployement in Indonesia (Pengangguran di Indonesia), www.indonesia-investments.com, acces date : June 2016

[18] Anonym, PNS taxable rationalization join the training prepared to be productive (www.newshub.asia), acces date : June 2016

[19] Entzian, Mareike Minimum Wage In ASEAN - all you need to know, 2016

[20] Table from Graphic, www. Kabarburuh.com, acces date : June 2016

[21] Hendry, Davy, Economic Competitiveness and human capital : A nexus in Indonesian Case, Procedia Economic Competitiveness, 2012 